\title{
Transport Pollution in India
}

\author{
Khageshwar Singh Patel ${ }^{*}$, Dhananjay Sahu ${ }^{1}$, Shobhana Ramteke ${ }^{1}$, Borislav Blazhev ${ }^{2}$, \\ Laurent Matini' ${ }^{3}$, Eduardo Yubero ${ }^{4}$, Jan Hoinkis ${ }^{5}$ \\ ${ }^{1}$ School of Studies in Environmental Science, Pt. Ravishankar Shukla University, Raipur, India \\ ${ }^{2}$ Central Laboratory for Chemical Testing and Control, Sofia, Bulgaria \\ ${ }^{3}$ Department of Exact Sciences, E.N.S., Marien Ngouabi University, Brazzaville, Congo \\ ${ }^{4}$ Applied Physics Department, Miguel Hernandez University, Elche, Spain \\ ${ }^{5}$ Karlsruhe University of Applied Sciences, Karlsruhe, Germany \\ Email: *patelks55@hotmail.com
}

Received 7 July 2015; accepted 18 August 2015; published 21 August 2015

Copyright (C) 2015 by authors and Scientific Research Publishing Inc.

This work is licensed under the Creative Commons Attribution International License (CC BY).

http://creativecommons.org/licenses/by/4.0/

c) () Dpen Access

\section{Abstract}

Road dusts contribute a large fraction of air pollution in urban environment of India. In the present work, contamination assessment of ions and elements i.e. $\mathrm{F}^{-}, \mathrm{Cl}^{-}, \mathrm{NO}_{3}^{-}, \mathrm{SO}_{4}^{2-}, \mathrm{NH}_{4}^{+}, \mathrm{Na}^{+}, \mathrm{K}^{+}$, $\mathrm{Mg}^{2+}, \mathrm{Ca}^{2+}$, $\mathrm{As}, \mathrm{Cr}, \mathrm{Mn}, \mathrm{Fe}, \mathrm{Ni}, \mathrm{Cu}, \mathrm{Zn}, \mathrm{Pb}$ and $\mathrm{Hg}$ in the road dusts of the most industrialized area of central India: Raipur (capital, Chhattisgarh state) is described during year: 2008-2013. In year 2008, the mean content of the element i.e. $\mathrm{F}^{-}, \mathrm{Cl}^{-}, \mathrm{NO}_{3}^{-}, \mathrm{SO}_{4}^{2-}, \mathrm{NH}_{4}^{+}, \mathrm{Na}^{+}, \mathrm{K}^{+}, \mathrm{Mg}^{2+}, \mathrm{Ca}^{2+}, \mathrm{As}, \mathrm{Cr}, \mathrm{Mn}$, $\mathrm{Fe}, \mathrm{Ni}, \mathrm{Cu}, \mathrm{Zn}, \mathrm{Pb}$ and Hgin the dust $(\mathrm{n}=5)$ was found to be $292 \pm 112,5068 \pm 2445,927 \pm 280$, $3336 \pm 1315,155 \pm 65,4273 \pm 1761,1477 \pm 626,974 \pm 243,9809 \pm 2370,21.2 \pm 2.4,150 \pm 30$, $12,816 \pm 12,522,157,736 \pm 61,542,60 \pm 7,566 \pm 608,348 \pm 154,296 \pm 163$ and $0.10 \pm 0.09 \mathrm{mg} / \mathrm{kg}$ respectively. The enrichment, concentration variations and sources of the elements are discussed.

\section{Keywords}

Road Dust, Heavy Metals, Ions, Contamination, India

\section{Introduction}

Population growth and economic development in India are contributing many serious environmental calamities i.e. environmental pollution, global warming, climate change, etc. [1]. Motored vehicles for land transportation are the foremost transportation method and contribute a major fraction of air pollution [2]. Road transport air pollutants are fugitive in nature, including vehicle, non-vehicle exhaust and road related emissions [3]. The most

"Corresponding author. 
common contaminants in road dusts are metals, inorganic salts, aromatic hydrocarbons, etc. [4] [5]. Sever road dust contamination with toxic metals i.e. $\mathrm{Cr}, \mathrm{Mn}, \mathrm{Fe}, \mathrm{Ni}, \mathrm{Cu}, \mathrm{Zn}$ and $\mathrm{Pb}$, was reported due to vehicular emissions in various locations of the world [6]-[16]. In addition, the increased prevalence rate of the air borne diseases in the residents residing nearby the highway was reported [17] [18]. The vast urbanization and industrialization of Raipur city (capital of Chhattisgarh state, India) has been marked since last 10 years due to being one of the biggest market for materials i.e. steel, cement, coal and forest products in the country. Hence, in this work the road dust contamination of the highway of Raipur city by 18 elements i.e. $\mathrm{F}^{-}, \mathrm{Cl}^{-}, \mathrm{NO}_{3}^{-}, \mathrm{SO}_{4}^{2-}, \mathrm{NH}_{4}^{+}, \mathrm{Na}^{+}$, $\mathrm{K}^{+}, \mathrm{Mg}^{2+}, \mathrm{Ca}^{2+}$, As, $\mathrm{Cr}, \mathrm{Mn}, \mathrm{Fe}, \mathrm{Ni}, \mathrm{Cu}, \mathrm{Zn}, \mathrm{Pb}$ and $\mathrm{Hg}$, is described.

\section{Methods and Materials}

\subsection{Study Area}

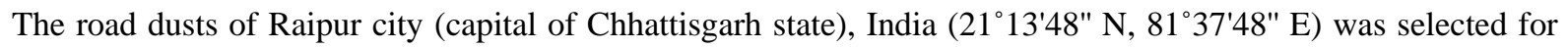
this study. The five locations i.e. Tatibandh, Pandari, Birgaon, Sakra and Sarora lie in the highway and freeway were selected for the sample collection, Figure 1. The road characteristics of sampling locations are summarized in Table 1. In addition, three locations i.e. Birgaon, Sakra and Sarora lie in the industrial environment. The traffic intensity (number of vehicles passing per day) in the highway was varied from 70,000 - 120,000, depending upon geography of the location. The samples were collected by using plastic spoon in month of May during years from 2008 to 2013. Four samples from different points of each location were collected, and a composite sample was prepared by mixing the min equal mass ratio. In year 2008, five composite samples were collected, one from each location. In other years, 2009-2013, two composite samples from locations: Birgaon and Sarora were collected in each year. They were kept in a glass bottle $(250 \mathrm{ml})$ and dried at $60^{\circ} \mathrm{C}$ in an oven for overnight. The samples were crushed into fine particles by mortar and sieved out the particles of mesh size $<100 \mu \mathrm{m}$.

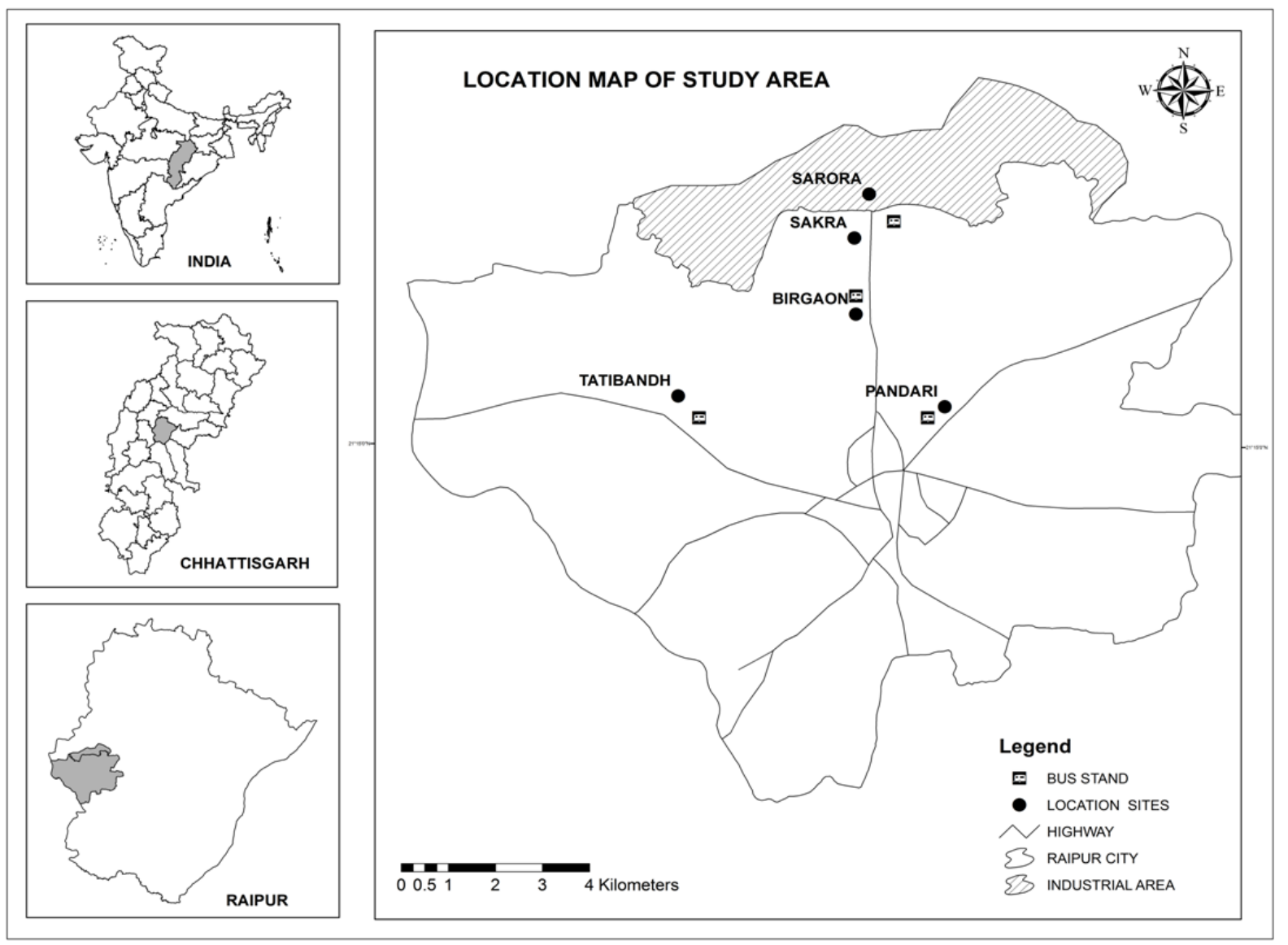

Figure 1. Representation of sampling locations in Raipur city. 
Table 1. Road characteristics.

\begin{tabular}{cccc}
\hline Site & Environmental characteristics & Road type & Traffic intensity per day \\
\hline Tatibandh & Outer area & Highway & 100,000 \\
Pandari & Urban area & Freeway & 120,000 \\
Birgaon & Urban area & Highway & 80,000 \\
Sakra & Industrial area & Highway & 70,000 \\
Sarora & Industrial area & Highway & 70,000 \\
\hline
\end{tabular}

\subsection{Analysis}

A $10.0 \mathrm{~g}$ dust sample was extracted with deionized hot water $(20 \mathrm{ml})$ for $6 \mathrm{hrs}$ in the utrasonic bath. The extract was filtered with microfilter of pore size, $2 \mu \mathrm{m}$ for measurment of $\mathrm{pH}$ value. Metrohm ion meter-781 equipped with fluoride ion selective electrode and calomel electrode was employed for monitoring of the fluoride content. The ion strength adjustment buffer (TISAB) was used in a 1:1 volume ratio, by dissolving $58 \mathrm{~g} \mathrm{NaCl,} 5.0 \mathrm{~g}$ trans-1, 2, NNNN, cyclodiamine tetra acetic acid and $57 \mathrm{ml}$ glacial acetic with pure water in 1 lit by subsequent adjustment of pH to 5.5 with $\mathrm{NaOH}$ solution. The Dionex DX120 ion chromatograph equipped with anion and cation separation columns and conductivity detector was employed for analysis of the ions.

The dust samples were digested with $\mathrm{HNO}_{3}: \mathrm{H}_{2} \mathrm{O}_{2}$ in closed vessel microwave digestion system (MARS 5). The Varian Liberty AX Sequential ICP-AES and Varian AA280FS atomic absorption spectrophotometer equipped VGA-77 (plasma flow: $15 \mathrm{l} / \mathrm{min}$, auxiliary flow: $1.5 \mathrm{l} / \mathrm{min}$, power: $1 \mathrm{KW}$, PMT voltage: $650 \mathrm{~V}$ ) were used for analysis of the metals in the dust. The VARIAN "SpectrAA" 55B equipped with hydride/cold vapor regenerator accessories was employed for determination of As and Hg. The urban dust reference material, QUA NAS from EU was used for the quality control.

The principal component analysis (PCA) method was used for analyzing relationships among the observed variables [19]. The statistical window software STATISTICA 7.1 was employed for the statistical analysis.

\section{Results and Discussion}

\subsection{Concentration of Ions}

The dusts were black in color with mean $\mathrm{pH}$ value $(\mathrm{n}=5)$ of $7.6 \pm 0.4$. The content of water soluble ions i.e. $\mathrm{F}^{-}$, $\mathrm{Cl}^{-}, \mathrm{NO}_{3}^{-}, \mathrm{SO}_{4}^{2-}, \mathrm{NH}_{4}^{+}, \mathrm{Na}^{+}, \mathrm{K}^{+}, \mathrm{Mg}^{2+}$ and $\mathrm{Ca}^{2+}$ in the road dusts was ranged from 195 - 486, $1615-8559$, 416 - 1230, 1112 - 4762, 48 - 252, 1902 - 6747, 785 - 2596, 699 - 1264 and 7219 - 13,708 mg/kg with mean value of $292 \pm 112,5068 \pm 2445,927 \pm 280,3336 \pm 1315,155 \pm 65,4273 \pm 1761,1477 \pm 626,974 \pm 243$ and $9809 \pm 2370 \mathrm{mg} / \mathrm{kg}$, respectively, Table 2 . Among them, $\mathrm{Ca}^{2+}$ had the highest content with the lowest value for $\mathrm{NH}_{4}^{+}$. The sum of the total content of 9 ions in the five locations of the road was ranged from $1.5 \%-3.6 \%$ with mean value of $2.4 \% \pm 0.7 \%$. The sum of total concentration of the ions was found to be well correlated $(r=0.94)$ with the traffic intensity. The highest fraction of the water soluble ions was observed in the vehicle stand sites (i.e. Tatibandh and Pandari), mainly due to input of the vehicle exhaust effluents, Figure 2.

\subsection{Concentration of Metals}

The metal content of the road dust is presented in Table 3. The content of the heavy metals (HMs) i.e. As, Cr, $\mathrm{Mn}, \mathrm{Fe}, \mathrm{Ni}, \mathrm{Cu}, \mathrm{Zn}, \mathrm{Pb}$ and $\mathrm{Hg}$ in the dust samples $(\mathrm{n}=5)$ was ranged from, 18.0 - 24.5, 101 - 178, 1871 37,809, 48,540 - 227,394, 52 - 74, $119-1720,166-603,165-617$ and $0.05-0.20 \mathrm{mg} / \mathrm{kg}$ with mean value of $21.2 \pm 2.4,150 \pm 30,12,816 \pm 12,522,157,736 \pm 61,542,60 \pm 7,566 \pm 608,348 \pm 154,296 \pm 163$ and $0.10 \pm$ $0.09 \mathrm{mg} / \mathrm{kg}$, respectively. The sum of the total content of 9 metals in the five locations of the road was ranged from 5.2\% - 26.6\% with mean value of $17.2 \% \pm 7.0 \%$. Among them, Fe and Mn exhibited higher content at the industrial sites, due to running of several iron industries in this region, Figure 2. However, three metals i.e. $\mathrm{Cu}$, $\mathrm{Zn}$ and $\mathrm{Pb}$ showed higher content at the vehicular sites, Figure 2. Their concentrations were found to be fairly correlated $(r=0.63$ - 0.95) with the traffic intensity. The heavy metal contents of the studied area was found to be much higher than other locations of the World, probably due to input of effluents by both vehicular and 
Table 2. Content of water soluble ions in road dust, $\mathrm{mg} / \mathrm{kg}$.

\begin{tabular}{ccccccccccc}
\hline Site & $\mathrm{F}^{-}$ & $\mathrm{Cl}^{-}$ & $\mathrm{NO}_{3}^{-}$ & $\mathrm{SO}_{4}^{2-}$ & $\mathrm{NH}_{4}^{+}$ & $\mathrm{Na}^{+}$ & $\mathrm{K}^{+}$ & $\mathrm{Mg}^{2+}$ & $\mathrm{Ca}^{2+}$ \\
\hline Tatibandh & 210 & 7102 & 1230 & 4762 & 252 & 5803 & 1656 & 1250 & 13,708 \\
Pandari & 360 & 8559 & 1058 & 4656 & 178 & 6747 & 2596 & 1264 & 11,497 \\
Birgaon & 486 & 4634 & 835 & 3338 & 136 & 4059 & 958 & 950 & 8324 \\
Sakra & 195 & 1615 & 416 & 1112 & 48 & 1902 & 785 & 699 & 8297 \\
Sarora & 210 & 3428 & 1096 & 2810 & 163 & 2852 & 1391 & 707 & 7219 \\
\hline
\end{tabular}

Table 3. Metal content of road dust, $\mathrm{mg} / \mathrm{kg}$.

\begin{tabular}{|c|c|c|c|c|c|c|c|c|c|}
\hline Site & As & $\mathrm{Cr}$ & Mn & $\mathrm{Fe}$ & $\mathrm{Ni}$ & $\mathrm{Cu}$ & $\mathrm{Zn}$ & $\mathrm{Pb}$ & $\mathrm{Hg}$ \\
\hline Tatibandh & 24.5 & 174 & 9011 & 162,284 & 58 & 1720 & 447 & 210 & 0.090 \\
\hline Pandari & 20.2 & 101 & 1871 & 48,540 & 52 & 719 & 603 & 617 & 0.197 \\
\hline Birgaon & 18.0 & 169 & 9274 & 141,250 & 60 & 151 & 233 & 165 & 0.079 \\
\hline Sakra & 23.4 & 178 & 6113 & 209,212 & 74 & 121 & 166 & 192 & 0.061 \\
\hline Sarora & 19.8 & 130 & 37,809 & 227,394 & 57 & 119 & 290 & 295 & 0.050 \\
\hline
\end{tabular}

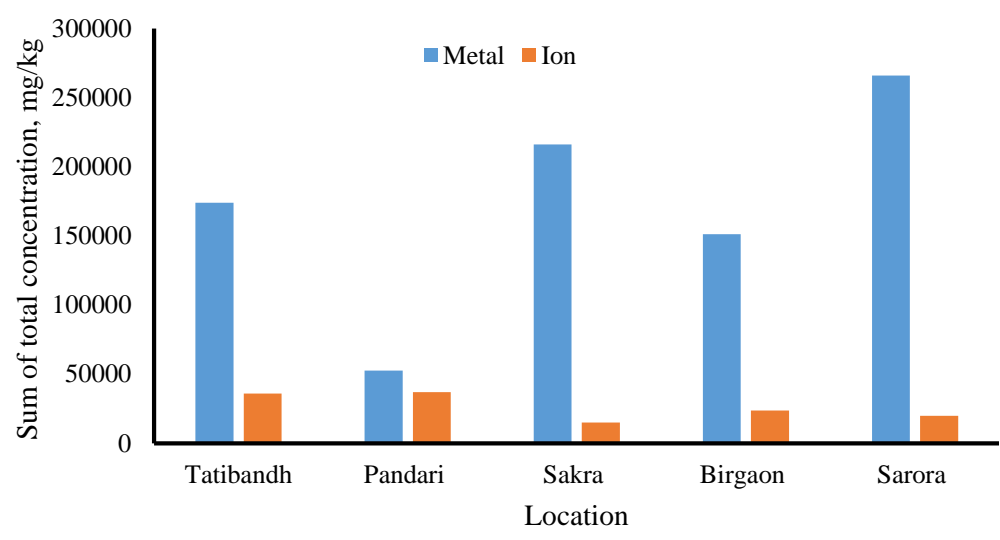

Figure 2. Total concentration of ions and metals in the road dust at five locations of Raipur city.

industrial emissions [6]-[16].

\subsection{Correlation, Enrichment and Sources}

The PCA analysis was executed on 17 variables (i.e. $\mathrm{Cl}^{-}, \mathrm{NO}_{3}^{-}, \mathrm{SO}_{4}^{2-}, \mathrm{NH}_{4}^{+}, \mathrm{Na}^{+}, \mathrm{K}^{+}, \mathrm{Mg}^{2+}, \mathrm{Ca}^{2+}, \mathrm{As}, \mathrm{Cr}$, $\mathrm{Mn}, \mathrm{Fe}, \mathrm{Ni}, \mathrm{Cu}, \mathrm{Zn}, \mathrm{Pb}$ and $\mathrm{Hg}$ ) for the 5 sample sites, Table 4. Four factors were extracted and accounted for $94.76 \%$ of the total variance. Factor- 1 accounted for $50.22 \%$ of the total variance. The variables $\mathrm{Cl}^{-}, \mathrm{NO}_{3}^{-}$, $\mathrm{SO}_{4}^{2-}, \mathrm{NH}_{4}^{+}, \mathrm{Mg}^{2+}$ and $\mathrm{Ca}^{2+}$ was correlated with each one by a strong positive loading value. Sodium and $\mathrm{Cu}$ showed some moderate loading values on Factor-1, and characterized by the presence of salts and organic matter for which $\mathrm{Cu}$ had a great affinity. Factor-2 accounted for $22.50 \%$ of the total variance. Chromium and Ni had a strong positive loading value, and Fe presented a moderate loading value. Mercury had a negative loading value on Factor-2, by denoting different sources between Cr, Ni and Hg. Factor-3 represented a $14.23 \%$ of the total variance. Manganese showed absolute strong loading values on Factor-3. Manganese was in opposite relation with metals such as $\mathrm{Pb}, \mathrm{Zn}, \mathrm{Cr}, \mathrm{Cu}, \mathrm{Ni}$ and $\mathrm{Fe}$. This could be explained by the different sources of $\mathrm{Mn}$ in relation to the trace metals cited above. Factor- 4 accounted for $7.81 \%$ of the total variance. Metals i.e. $\mathrm{Pb}, \mathrm{Zn}$ and $\mathrm{K}^{+}$had each one a strong positive loading value on factor- 4 . Arsenic presented a negative loading value, this denoted 
Table 4. Varimax factor matrix of chemical constituents.

\begin{tabular}{|c|c|c|c|c|}
\hline Parameter & Factor-1 & Factor-2 & Factor-3 & Factor-4 \\
\hline $\mathrm{Cl}^{-}$ & 0.80 & -0.07 & 0.11 & 0.57 \\
\hline $\mathrm{NO}_{3}^{-}$ & 0.80 & -0.07 & -0.43 & 0.40 \\
\hline $\mathrm{SO}_{4}^{2-}$ & 0.92 & -0.20 & 0.02 & 0.26 \\
\hline $\mathrm{NH}_{4}^{+}$ & 0.83 & -0.13 & -0.28 & 0.31 \\
\hline $\mathrm{Na}^{+}$ & 0.77 & -0.25 & 0.23 & 0.54 \\
\hline $\mathrm{K}^{+}$ & 0.47 & -0.20 & 0.03 & 0.85 \\
\hline $\mathrm{Mg}^{2+}$ & 0.96 & 0.03 & 0.19 & 0.17 \\
\hline $\mathrm{Ca}^{2+}$ & 0.96 & 0.13 & 0.21 & 0.03 \\
\hline $\mathrm{Hg}$ & 0.33 & -0.74 & 0.47 & 0.20 \\
\hline $\mathrm{Fe}$ & -0.17 & 0.73 & -0.59 & -0.27 \\
\hline $\mathrm{Mn}$ & -0.05 & 0.22 & -0.97 & 0.05 \\
\hline $\mathrm{Cu}$ & 0.77 & 0.27 & 0.14 & 0.28 \\
\hline $\mathrm{Cr}$ & 0.05 & 0.98 & 0.00 & 0.04 \\
\hline $\mathrm{Ni}$ & 0.12 & 0.87 & -0.01 & 0.05 \\
\hline $\mathrm{Pb}$ & 0.22 & -0.01 & -0.08 & 0.96 \\
\hline $\mathrm{Zn}$ & 0.47 & 0.17 & 0.02 & 0.86 \\
\hline As & -0.18 & 0.08 & 0.52 & -0.79 \\
\hline Eigenvalue & 9.04 & 4.05 & 2.56 & 1.41 \\
\hline \% Variance & 50.22 & 22.50 & 14.23 & 7.81 \\
\hline Cumulative \% & 50.22 & 72.72 & 86.95 & 94.76 \\
\hline
\end{tabular}

Absolute loading values $>0.70$, significant at $\mathrm{p}<0.05$.

also different source between $\mathrm{Pb}$ and $\mathrm{Zn}$. Vehicular emissions, industrial discharges and urban development are as much sources of heavy metals loadings [20]-[24]. Therefore, the metal deposition over time led to enrichment and caused metal contamination of the dust [4]. Among these metals, As and Hg showed others sources in relation to $\mathrm{Pb}, \mathrm{Zn}, \mathrm{Cr}, \mathrm{Cu}, \mathrm{Ni}$ and $\mathrm{Zn}$. A 1:1 mass concentration ratio of $\mathrm{Zn}$ and $\mathrm{Pb}$ in the road dust was found, and their prominent sources expected in the dust are $\mathrm{ZnO}$ and $\mathrm{Pb}$ used in tire thread and in the motor vehicle wheel balance weights, respectively [25]. Among these sources, vehicular emission was a significant and increasing source of road and soil pollution in urban area. Heavy metals in such environment can come from trimming brake, mechanical abrasion as essential components of many alloy, pipe, wire and tire in motor vehicles. One of the atmospheric pollutants released from vehicular traffic was heavy metals, which can accumulate in surface road and soil from elevated emissions.

The correlation matrix of the ions and metals in the road dusts are presented in Table 5, Table 6. All ions (except $\mathrm{F}^{-}$) among themselves had fair to excellent correlation, indicating their common sources, Table 5. The content of metals i.e. $\mathrm{Cr}, \mathrm{Mn}$ and $\mathrm{Ni}$ among themselves had fair correlation, showing their common origins, Table 6. Iron content had fair correlation with metals i.e. $\mathrm{Cr}, \mathrm{Mn}$ and $\mathrm{Ni}$, indicating origin from steel industry and coal burning effluents.

In this study, the average composition of upper crust is used as crustal reference materials [26]. The mean value of $\mathrm{Al}$ content in the road dust of the study area was found to be $0.86 \%$. The $\mathrm{E}_{\mathrm{f}}$ value for species i.e. $\mathrm{Ni}, \mathrm{Cr}$, $\mathrm{Hg}, \mathrm{Fe}, \mathrm{As}, \mathrm{Mn}, \mathrm{Pb}, \mathrm{Cu}, \mathrm{Zn}, \mathrm{Cl}^{-}$and $\mathrm{SO}_{4}^{2-}$ was evaluated, and presented in Figure 3. The enrichment value $\left(\mathrm{E}_{\mathrm{f}}\right)$ was grouped into moderately, significantly and highly enriched classes. The first elemental group $\left(\mathrm{Cl}^{-}, \mathrm{SO}_{4}^{2-}\right.$, 
Table 5. Correlation matrix of metal (r).

\begin{tabular}{|c|c|c|c|c|c|c|c|c|c|}
\hline & $\mathrm{F}^{-}$ & $\mathrm{Cl}^{-}$ & $\mathrm{NO}_{3}^{-}$ & $\mathrm{SO}_{4}^{2-}$ & $\mathrm{NH}_{4}^{+}$ & $\mathrm{Na}^{+}$ & $\mathrm{K}^{+}$ & $\mathrm{Mg}^{2+}$ & $\mathrm{Ca}^{2+}$ \\
\hline $\mathrm{F}^{-}$ & 1.00 & & & & & & & & \\
\hline $\mathrm{Cl}^{-}$ & 0.32 & 1.00 & & & & & & & \\
\hline $\mathrm{NO}_{3}^{-}$ & 0.00 & 0.73 & 1.00 & & & & & & \\
\hline $\mathrm{SO}_{4}^{2-}$ & 0.30 & 0.96 & 0.86 & 1.00 & & & & & \\
\hline $\mathrm{NH}_{4}^{+}$ & 0.00 & 0.78 & 0.96 & 0.91 & 1.00 & & & & \\
\hline $\mathrm{Na}^{+}$ & 0.32 & 1.00 & 0.69 & 0.95 & 0.73 & 1.00 & & & \\
\hline $\mathrm{K}^{+}$ & 0.30 & 0.88 & 0.65 & 0.77 & 0.60 & 0.85 & 1.00 & & \\
\hline $\mathrm{Mg}^{2+}$ & 0.28 & 0.96 & 0.62 & 0.92 & 0.75 & 0.97 & 0.75 & 1.00 & \\
\hline $\mathrm{Ca}^{2+}$ & 0.30 & 0.79 & 0.54 & 0.77 & 0.73 & 0.45 & 0.6 & 0.91 & 1.00 \\
\hline
\end{tabular}

Table 6. Correlation matrix of metal (r).

\begin{tabular}{|c|c|c|c|c|c|c|c|c|c|}
\hline & As & $\mathrm{Cr}$ & $\mathrm{Mn}$ & $\mathrm{Fe}$ & $\mathrm{Ni}$ & $\mathrm{Cu}$ & $\mathrm{Zn}$ & $\mathrm{Pb}$ & $\mathrm{Hg}$ \\
\hline As & 1.00 & & & & & & & & \\
\hline $\mathrm{Cr}$ & 0.24 & 1.00 & & & & & & & \\
\hline $\mathrm{Mn}$ & -0.50 & 0.10 & 1.00 & & & & & & \\
\hline $\mathrm{Fe}$ & 0.00 & 0.66 & 0.69 & 1.00 & & & & & \\
\hline $\mathrm{Ni}$ & 0.40 & 0.79 & 0.00 & 0.68 & 1.00 & & & & \\
\hline $\mathrm{Cu}$ & 0.36 & 0.26 & -0.22 & -0.14 & -0.14 & 1.00 & & & \\
\hline $\mathrm{Zn}$ & -0.79 & 0.00 & 0.10 & -0.36 & -0.36 & 0.66 & 1.00 & & \\
\hline $\mathrm{Pb}$ & -0.82 & 0.24 & 0.00 & -0.40 & -0.30 & 0.66 & 0.90 & 1.00 & \\
\hline $\mathrm{Hg}$ & 0.00 & -0.79 & -0.20 & -0.94 & -0.71 & 0.26 & 0.26 & 0.35 & 1.00 \\
\hline
\end{tabular}

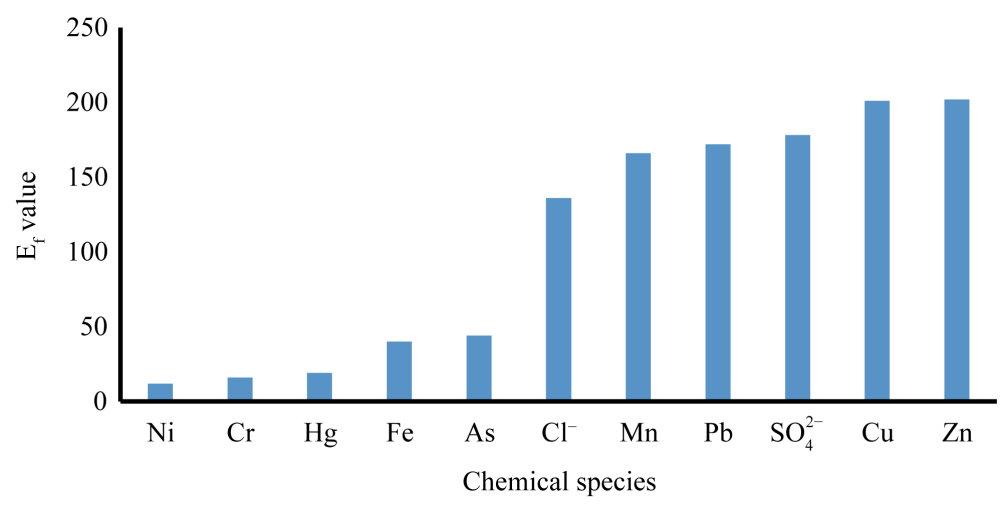

Figure 3. Mean $\mathrm{E}_{\mathrm{f}}$ value of metals in the road dust of Raipur city.

$\mathrm{Mn}, \mathrm{Cu}, \mathrm{Pb}$ and $\mathrm{Zn}$ ) showed a strong $\mathrm{E}_{\mathrm{f}}$ value (>100), could be considered as anthropogenic elements. The second group elements (i.e. Fe and As) showed a significant $\mathrm{E}_{\mathrm{f}}$ values $(>20-<50)$, could be considered of anthropogenic and crustal origin. The third group elements (i.e. $\mathrm{Cr}$, $\mathrm{Ni}$ and $\mathrm{Hg}$ ) having $\mathrm{E}_{\mathrm{f}}$ value of $<20$, could be considered as elements of crustal origin. 

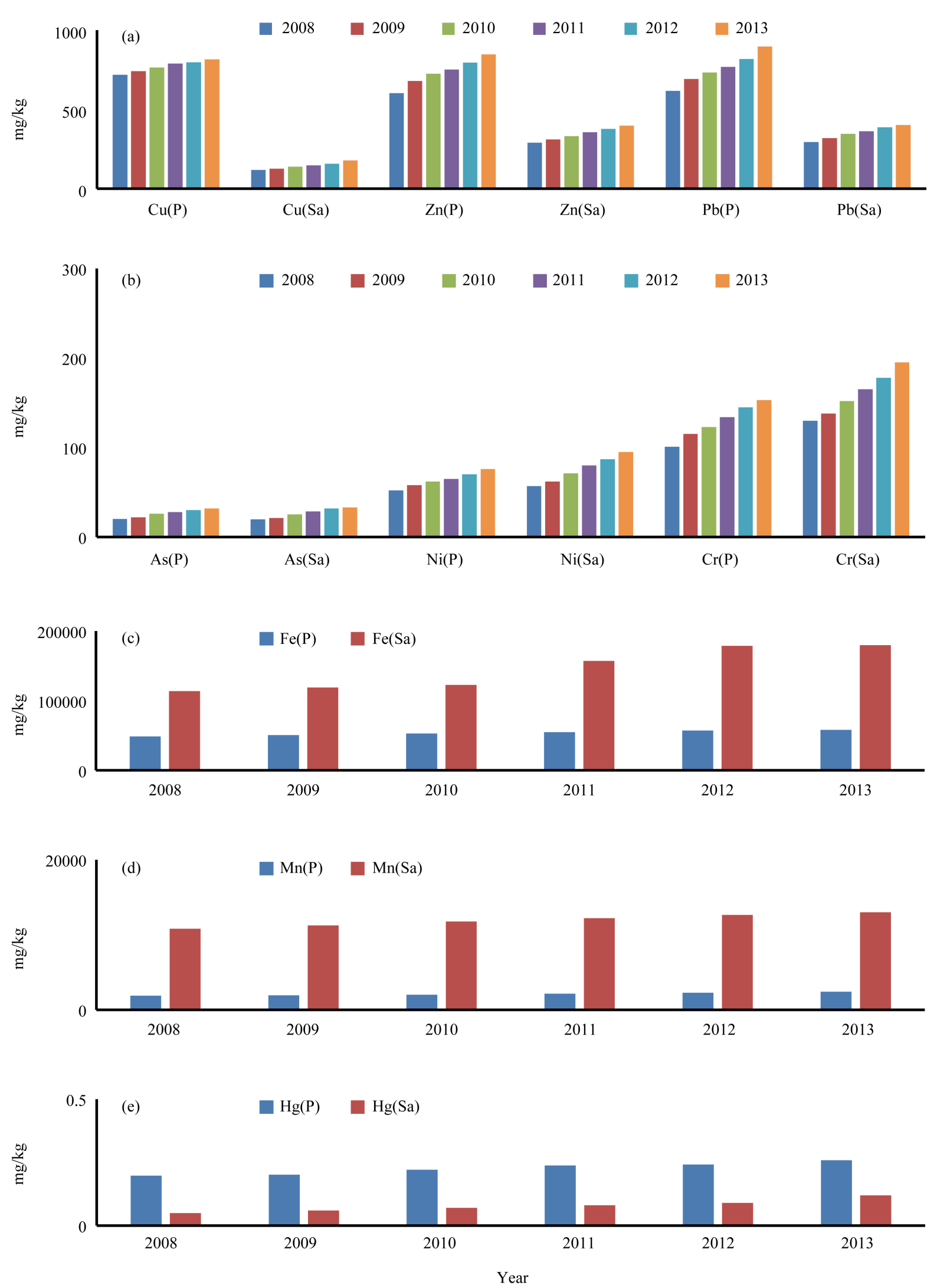

(A) 

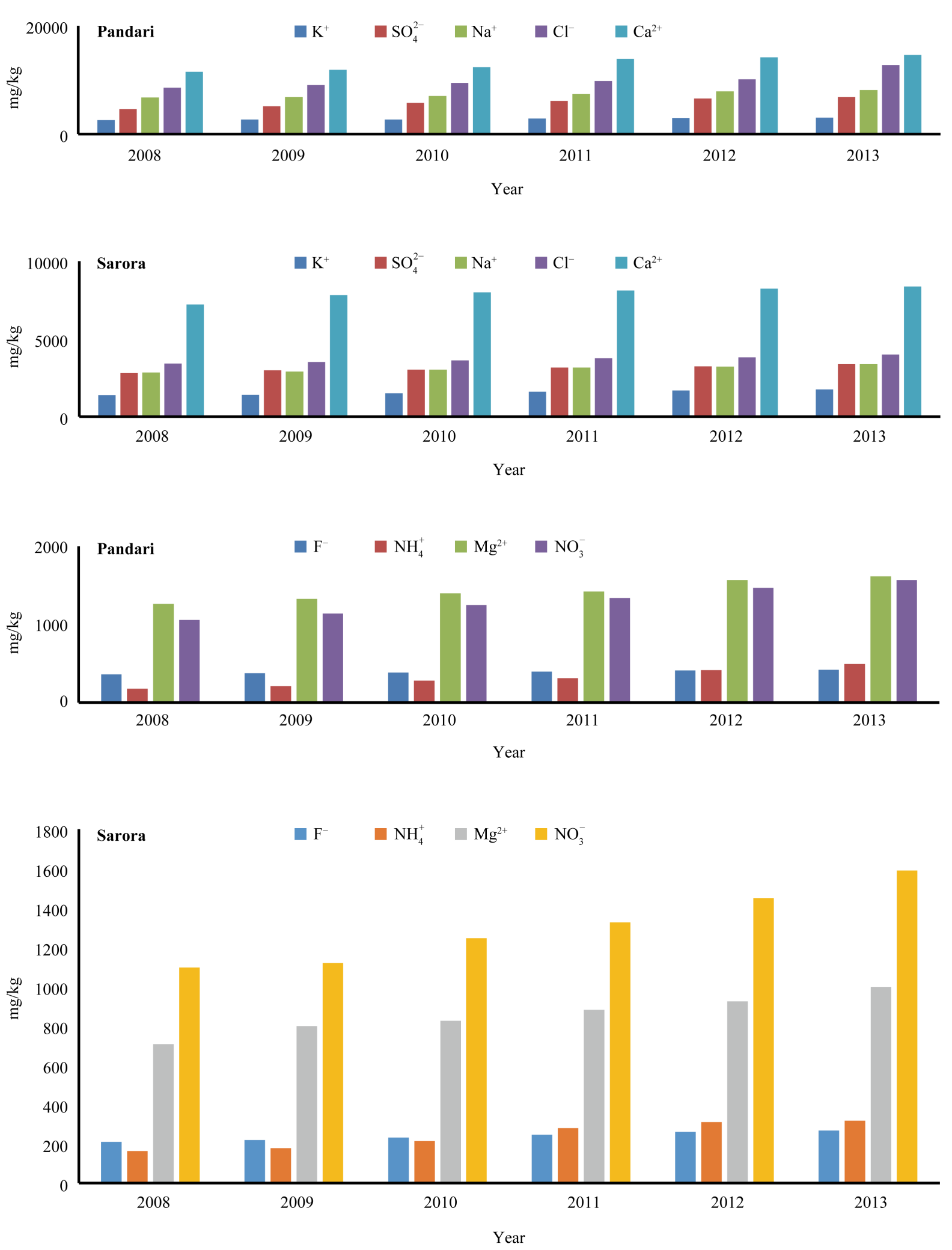

(B)

Figure 4. (A) Temporal variation of metal concentration in road dust of Raipur city at two lacations: $\mathrm{P}=$ Pandari, Sa $=$ Sarora; (B) Temporal variation of ion concentration in road dust of Raipur city at two locations. 


\subsection{Chemical Composition of Dust}

The sum of total content of the heavy metals and water soluble ions were varied from $8.9 \%-28.6 \%$ with mean value of $18.2 \% \pm 6.9 \%$ in the dust. The mean value of Fe, $\mathrm{Mn}$ and $\mathrm{Ca}$ in the dust was $15.0 \pm 6.1,1.3 \pm 1.2$ and $1.0 \% \pm 0.3 \%$, respectively. The contribution of other species i.e. As, $\mathrm{Ni}, \mathrm{Cu}, \mathrm{Zn}, \mathrm{Pb}$ and $\mathrm{Zn}$ was accounted to $\approx$ $0.14 \% \pm 0.09 \%$. The sum of mean value for the water soluble ions i.e. $\mathrm{F}^{-}, \mathrm{Cl}^{-}, \mathrm{NO}_{3}^{-}, \mathrm{SO}_{4}^{2-}, \mathrm{NH}_{4}^{+}, \mathrm{Na}^{+}, \mathrm{K}^{+}$, $\mathrm{Mg}^{2+}$ and $\mathrm{Ca}^{2+}$ in the dust was $2.6 \% \pm 0.9 \%$. The uncertainty in the dust was $\approx 80.2 \%$, which may include carbons, silica, alumina, organics, etc.

\subsection{Temporal Variation of Dust Constituents}

The temporal variation studies in the dust contamination were carried out from years 2008 to 2013, Figure 4(A), Figure 4(B). The elements i.e. $\mathrm{Cl}^{-}, \mathrm{SO}_{4}^{2-}, \mathrm{NO}_{3}^{-}, \mathrm{Cu}, \mathrm{Pb}$ and $\mathrm{Zn}$ were largely emitted by the transport vehicles. Other elements i.e. $\mathrm{Na}, \mathrm{K}, \mathrm{Mg}, \mathrm{Ca}, \mathrm{As}, \mathrm{Cr}, \mathrm{Fe}, \mathrm{Ni}$ and $\mathrm{Hg}$ were emitted by the multiple sources i.e. industrial, vehicular and tire exhausts and crustal materials. The concentration of contaminants related to vehicular effluents was extremely increased in the traffic area of the highway road due to tremendous enhancement in the vehicle frequency, Figure 4(A), Figure 4(B).

\section{Conclusion}

An enormous enrichment of species i.e. $\mathrm{Cl}^{-}, \mathrm{SO}_{4}^{2-}, \mathrm{Mn}, \mathrm{Cu}, \mathrm{Pb}$ and $\mathrm{Zn}$ is seen in the heavily rushed vehicle stand sites of the city due to transport effluents. Both correlation analysis and principal component analysis (PCA) were used to determine the sources of the heavy metals and ions. The result gave four components which were natural crust, industrial effluent, vehicular emission, and wear of vehicle parts. A higher temporal variation of species emitted by vehicles was observed.

\section{Acknowledgements}

We are thankful to the Alexander von Humboldt Foundation, Bonn for the award of fellowship to one of the author: KSP.

\section{References}

[1] Schwela, D. (2006) Urban Air Pollution in Asian Cities: Status, Challenges and Management. Earthscan, London and Sterling.

[2] Perry, A.H. and Symons, J. (2003) Highway Meteorology (Kindle Edition). Taylor \& Francis, London.

[3] Morgenstern, V., Zutavern, A., Cyrys, J., Brockow, I., Koletzko, S., Krämer, U., Behrendt, H., Herbarth, O., Berg, A.V., Bauer, C.P., Wichmann, H.E. and Heinrich, J. (2008) Atopic Diseases, Allergic Sensitization, and Exposure to Traffic-Related Air Pollution in Children. American Journal of Respiratory and Critical Care Medicine, 177, 13311337. http://dx.doi.org/10.1164/rccm.200701-036OC

[4] Han, L., Zhuang, G., Cheng, S., Wang, Y. and Li, J. (2007) Characteristics of Re-Suspended Road Dust and Its Impact on the Atmospheric Environment in Beijing. Atmospheric Environment, 41, 7485-7499. http://dx.doi.org/10.1016/j.atmosenv.2007.05.044

[5] Liu, M., Cheng, S.B., Ou, D.N., Hou, L.J., Gao, L., Wang, L.L., Xie, Y.S., Yang, Y. and Xu, S.Y. (2007) Characterization, Identification of Road Dust PAHs in Central Shanghai Areas, China. Atmospheric Environment, 41, 8785-8795. http://dx.doi.org/10.1016/j.atmosenv.2007.07.059

[6] Charlesworth, S., Everett, M., McCarthy, R., Ordonez, A. and De Miguel, E. (2003) Comparative Study of Heavy Metal Concentration and Distribution in Deposited Street Dusts in a Large and a Small Urban Area: Birmingham and Coventry, West Midlands, UK. Environment International, 29, 563-573. http://dx.doi.org/10.1016/S0160-4120(03)00015-1

[7] Faiz, Y., Tufail, M., Javed, M.T., Chaudhry, M.M. and Siddique, N. (2009) Road Dust Pollution of Cd, Cu, Ni, Pb and Zn along Islamabad Expressway, Pakistan. Microchemical Journal, 92, 186-192.

[8] Shinggu, D.Y., Ogugbuaja, V.O., Baminas, J.T. and Toma, I. (2007) Analysis of Street Dust for Heavy Metal Pollutants in Mubi, Adamawa State, Nigeria. International Journal of Physical Science, 2, 290-293. http://www.academicjournals.org/IJPS

[9] Atiemo, M.S., Ofosu, G.F., Kuranchie-Mensah, H., Tutu, A.O., Linda Palm, N.D.M. and Blankson, S.A. (2011) Con- 
tamination Assessment of Heavy Metals in Road Dust from Selected Roads in Accra, Ghana. Research Journal of Environmental and Earth Sciences, 3, 473-480.

[10] Wei, B. and Yang, L. (2010) A Review of Heavy Metal Contaminations in Urban Soils, Urban Road Dusts and Agricultural Soils from China. Microchemical Journal, 94, 99-107. http://dx.doi.org/10.1016/j.microc.2009.09.014

[11] Lee, P.K., Youm, S.J. and Jo, H.Y. (2013) Heavy Metal Concentrations and Contamination Levels from Asian Dust and Identification of Sources: A Case Study. Chemosphere, 91, 1018-1025. http://dx.doi.org/10.1016/j.chemosphere.2013.01.074

[12] Du, Y., Gao, B., Zhou, H., Ju, X., Hao, H. and Yin, S. (2013) Health Risk Assessment of Heavy Metals in Road Dusts in Urban Parks of Beijing, China. Procedia Environmental Sciences, 18, 299-309. http://dx.doi.org/10.1016/j.proenv.2013.04.039

[13] Victoria, A., Cobbina, S.J., Dampare, S.B. and Duwiejuah, A.B. (2014) Heavy Metals Concentration in Road Dust in the Bolgatanga Municipality, Ghana. Journal of Environment Pollution and Human Health, 2, 74-80.

[14] Ubwa, S.T., Abah, J., Ada, C.A. and Alechenu, E. (2013) Levels of Some Heavy Metals Contamination of Street Dust in the Industrial and High Traffic Density Areas of Jos Metropolis. Journal of Biodiversity and Environmental Sciences, 3, 13-21.

[15] Rajaram, B.S., Suryawanshi, P.V., Bhanarkar, A.D. and Rao, C.V.C. (2014) Heavy Metals Contamination in Road Dust in Delhi City, India. Environmental Earth Sciences, 72, 3929-3938. http://dx.doi.org/10.1007/s12665-014-3281-y

[16] Cerda, E.V., Reyes, L.H., Barbosa, J.M.A., Elizondo-Martinez, P. and Acuña-Askar, K. (2011) Contamination and Chemical Fractionation of Heavy Metals in Street Dust from the Metropolitan Area of Monterrey, Mexico. Environmental Technology, 32, 1163-1172. http://dx.doi.org/10.1080/09593330.2010.529466

[17] Brugge, D., Durant, J.L. and Rioux, C. (2007) Near-High Way Pollutants in Motor Vehicle Exhaust: A Review of Epidemiologic Evidence of Cardiac and Pulmonary Health Risks. Environmental Health, 6, 8-13. http://dx.doi.org/10.1186/1476-069x-6-23

[18] Ferguson, E., Maheswaran, R. and Daly, M. (2004) Road-Traffic Pollution and Asthma-Using Modelled Exposure Assessment for Routine Public Health Surveillance. International Journal of Health Geographics, 3, 24. http://dx.doi.org/10.1186/1476-072X-3-24

[19] Loska, K. and Wiechuya, D. (2003) Application of Principle Component Analysis for the Estimation of Source of Heavy Metal Contamination in Surface Sediments from the Rybnik Reservoir. Chemosphere, 51,723-733. http://dx.doi.org/10.1016/S0045-6535(03)00187-5

[20] Surthland, R.A., Tolosa, C.A., Tack, F.M.G. and Verloo, M.G. (2000) Characterization of Selected Element Concentrations and Enrichment Ratios in Background and Anthropogenically Impacted Roadside Areas. Archive of Environmental Contamination and Toxicology, 38, 428-438.

[21] Biasioli, M., Barberi, R. and Ajmone-Marsan, F. (2006) The Influence of a Large City on Some Soil Properties and Metals Content. The Science of the Total Environment, 356, 154-164. http://dx.doi.org/10.1016/j.scitotenv.2005.04.033

[22] Chen, T.B., Zheng, Y.M., Lei, M., Huang, Z.C., Wu, H.T., Chen, H., Fan, K.K., Yu, K., Wu, X. and Tian, Q.Z. (2005) Assessment of Heavy Metal Pollution in Surface Soils of Urban Parks in Beijing, China. Chemosphere, 60, 542-551. http://dx.doi.org/10.1016/j.chemosphere.2004.12.072

[23] Lee, C.S., Li, X., Shi, W., Cheung, S.C. and Thornton, I. (2006) Metal Contamination in Urban, Suburban, and Country Park Soils of Hong Kong: A Study Based on GIS and Multivariate Statistics. Science of Total Environment, 356, 45-61. http://dx.doi.org/10.1016/j.scitotenv.2005.03.024

[24] Duzgoren-Aydin, N.S., Wong, C.S.C., Song, Z.G., Aydin, A., Li, X.D. and You, M. (2006) Fate of Heavy Metal Contaminants in Road Dusts and Gully Sediments in Guangzhou, SE China: A Chemical and Mineralogical Assessment. Human and Ecological Risk Assessment, 12, 374-389. http://dx.doi.org/10.1080/10807030500538005

[25] Adachi, K. and Tainosho, Y. (2004) Characterization of Heavy Metal Particles Embedded in Tire Dust. Environmental International, 30, 1009-1017. http://dx.doi.org/10.1016/j.envint.2004.04.004

[26] Rudnick, R.L. and Gao, S. (2003) The Composition of the Continental Crust. In: Holland, H.D. and Turekian, K.K., Eds., Treatise on Geochemistry, Elsevier-Pergamon, Oxford, 1-64. 